\title{
Construction Engineering Project Phase Hidden Costs of Control Strategies
}

\author{
Shuyang Liu'1, Jiaye $\mathrm{Wu}^{2 *}$, Yue Yue${ }^{1}$, Yingqian Zhang² \\ ${ }^{1}$ School of Management of Sichuan University of Science \& Engineering, Zigong, China \\ ${ }^{2}$ School of Civil Engineering of Sichuan University of Science \& Engineering, Zigong, China \\ Email:*931074431@qq.com
}

How to cite this paper: Liu, S.Y., Wu, J.Y., Yue, Y. and Zhang, Y.Q. (2019) Construction Engineering Project Phase Hidden Costs of Control Strategies. Open Access Library Journal, 6: e5682.

https://doi.org/10.4236/oalib.1105682

Received: August 8, 2019

Accepted: August 26, 2019

Published: August 29, 2019

Copyright $\odot 2019$ by author(s) and Open Access Library Inc.

This work is licensed under the Creative Commons Attribution International License (CC BY 4.0).

http://creativecommons.org/licenses/by/4.0/

\begin{abstract}
In recent years, the scale of China's construction industry has been expanding, and construction companies have gradually revealed some problems. Among them, cost management issues are more prominent, especially the management of hidden costs. Because of its strong concealment, the structure is more complicated and difficult to quantify. As a result, a complete research system has not yet been formed. This paper analyzes the influencing factors of construction engineering project in construction stage of the four levels of technology, management, contract and society, uses the expert scoring method to determine the main influencing factors, and proposes the main influencing factors.
\end{abstract}

\section{Subject Areas}

Engineering Management

\section{Keywords}

Construction Project, Hidden Cost, Control Strategy

\section{Introduction}

In recent years, China has made rapid progress in construction projects. With the increase in construction projects in China, construction companies have achieved the goal of production and operation and obtained profits. The control of construction project cost has a close relationship with the acquisition of profits. The cost of construction projects includes not only explicit costs, but also hidden costs that are hard to quantify. From the contemporary point of view, the management of most construction projects only considers how to manage from 
the perspective of explicit cost, and does not consider it from the perspective of hidden costs. The hidden cost is the same as the categorical cost, which is the part of the total cost of the project that cannot be ignored. If you do not pay attention to hiding costs and do not control hidden costs, you will lose the benefits of the company to a large extent. Therefore, only when the hidden costs are made seriously, and the full understanding and effective control can obtain the maximum benefits [1]-[7].

\section{Basic Concept Definition}

\subsection{Concealed Cost Concept in the Construction Phase of a Construction Project}

There are different conclusions when analyzing enterprise costs from different angles, but the cost is easily forgotten by managers. For example, due to unreasonable corporate structure, imperfect systems, and technical defects, these costs will increase, and these costs and significant costs will increase. Compared with the characteristics of large concealment and difficulty in quantification, it is called hidden cost [8]. Simply put, the hidden cost is the hidden cost of the behavior that the company or employee intentionally or unintentionally makes, so that it exists in the total cost and is not financial.

\subsection{Implicit Cost Performance Forms during Construction Phase of the Construction Project}

Construction projects have different manifestations at different times during the construction phase, as shown in Table 1.

\section{Analysis of Factors Affecting the Hidden Cost of Construction Engineering Projects}

As the most important stage of the construction project, the construction phase depends on resources, environment, technical conditions and other factors. The cost of construction projects as a reflection of the value of their production processes is also determined by these basic factors [9]. The index system of the influencing factors of hidden costs in the construction phase of construction projects is shown in Table 2.

\section{Expert Evaluation of Research Factors on Hidden Costs}

Main issuing units of this questionnaire are the main parties of construction projects such as construction units, construction units and supervision units. The personnel involved in the questionnaire are mainly the management personnel of these units. The questionnaire uses the numbers $5,4,3,2$, and 1 , respectively, to indicate that the degree of impact of hidden costs has a large impact, a large impact, a general influence, a slight impact, and no impact. A total of 100 questionnaires were published. After the experts filled out, 86 of them 
Table 1. The form of hiding costs.

\begin{tabular}{|c|c|}
\hline Manifestations & Cost increase reason \\
\hline Institutional cost & Unreasonable corporate structure and imperfect system \\
\hline Mechanism cost & $\begin{array}{l}\text { The reward and punishment system is unreasonable, the incentive } \\
\text { system is imperfect, and supporting measures are not implemented. }\end{array}$ \\
\hline Staff quality cost & Poor quality of management personnel and construction personnel \\
\hline Quality cost & Increase the cost of quality \\
\hline Duration of construction & Project delay due to contractor reasons \\
\hline Safety cost & Protection of people, materials, and equipment \\
\hline
\end{tabular}

Table 2. Index system for influencing factors of hidden costs in the construction phase of construction projects.

\begin{tabular}{|c|c|c|}
\hline Target layer & Criteria layer & Indicator layer \\
\hline \multirow{31}{*}{$\begin{array}{l}\text { Index system for } \\
\text { influencing factors of } \\
\text { hidden costs in the } \\
\text { construction phase of } \\
\text { construction projects A }\end{array}$} & \multirow{10}{*}{$\begin{array}{l}\text { Management } \\
\text { factor } B_{1}\end{array}$} & Initiative for staff work $C_{1}$ \\
\hline & & Information flow control level $\mathrm{C}_{2}$ \\
\hline & & Professional competence and technical level $\mathrm{C}_{3}$ \\
\hline & & $\begin{array}{l}\text { Information collection, organization and analysis } \\
\text { capabilities } C_{4}\end{array}$ \\
\hline & & Subcontract management $\mathrm{C}_{5}$ \\
\hline & & Mechanical equipment repair and maintenance $\mathrm{C}_{6}$ \\
\hline & & Leadership decision level $\mathrm{C}_{7}$ \\
\hline & & The degree of perfection of the system and mechanism $\mathrm{C}_{8}$ \\
\hline & & Information transfer rate $\mathrm{C}_{9}$ \\
\hline & & Safety production management $\mathrm{C}_{10}$ \\
\hline & \multirow{9}{*}{$\begin{array}{l}\text { Technical } \\
\text { factor } \mathrm{B}_{2}\end{array}$} & Management organizational structure design $C_{11}$ \\
\hline & & Quality assurance $\mathrm{C}_{12}$ \\
\hline & & Construction schedule $\mathrm{C}_{13}$ \\
\hline & & Duration guarantee $\mathrm{C}_{14}$ \\
\hline & & $\begin{array}{l}\text { Determination of major construction steps and technical } \\
\text { plans } C_{15}\end{array}$ \\
\hline & & $\begin{array}{l}\text { Construction deployment and selection of construction } \\
\text { methods } \mathrm{C}_{16}\end{array}$ \\
\hline & & Construction site layout $\mathrm{C}_{17}$ \\
\hline & & Construction machinery and equipment selection $\mathrm{C}_{18}$ \\
\hline & & Progress payment amount $\mathrm{C}_{19}$ \\
\hline & \multirow{5}{*}{$\begin{array}{l}\text { Contract } \\
\text { factor } \mathrm{B}_{3}\end{array}$} & Project changes $\mathrm{C}_{20}$ \\
\hline & & Pad production $\mathrm{C}_{21}$ \\
\hline & & Timeliness of claim $\mathrm{C}_{22}$ \\
\hline & & Material equipment supply $\mathrm{C}_{23}$ \\
\hline & & Contract clause modification $\mathrm{C}_{24}$ \\
\hline & \multirow{7}{*}{$\begin{array}{c}\text { Social } \\
\text { environmental } \\
\text { factors } \mathrm{B}_{4}\end{array}$} & Change in raw material prices $\mathrm{C}_{25}$ \\
\hline & & force majeure $\mathrm{C}_{26}$ \\
\hline & & Changes in laws and regulations $\mathrm{C}_{27}$ \\
\hline & & Industry policy adjustment $\mathrm{C}_{28}$ \\
\hline & & Engineering geological conditions $\mathrm{C}_{29}$ \\
\hline & & Inflation $\mathrm{C}_{30}$ \\
\hline & & Social security around the project $\mathrm{C}_{31}$ \\
\hline
\end{tabular}


finally collect. After analysis, 4 out of the requirements were found, so the final valid questionnaire was 82 . The recovery rate of the questionnaire is $82 \%$. In order to ensure the reliability of the collected data, the reliability of the data has to be tested. This paper uses the Cronbach $\alpha$ coefficient of SPSS20.0 software to test, the test result is $\alpha=0.856$, the data have reliability (Table 3, Table 4).

\section{Countermeasure Analysis of Recessive Cost Management in Strengthening Construction Projects}

\subsection{Setting a Reasonable Project Organization form}

In the analysis of the influential factors of the hidden cost of the construction phase of the construction project, it is found that the organizational form of the project has a high degree of influence on the hidden cost. Unreasonable organizational settings can result in a waste of resources. Therefore, choosing the appropriate organizational form of a construction project is one of the important measures to control the hidden cost of the construction phase.

In addition to considering the characteristics of the project organization form, the organizational form should be intended to meet the project objectives. In the organizational setting, the management scope should be effectively considered, and the organization's authority and responsibility should be clearly defined; at the same time, the management personnel in the organization should be optimized.

\subsection{Selection of Construction Methods}

The choice of different construction methods will result in distinctive hidden costs [10]. After the previous research, the impact of construction methods on hidden costs is very large. Therefore, choosing a reasonable construction process is one of the important measures to control the hidden costs in the construction phase.

There is a direct relationship between the construction method and the progress and quality of the construction. Choosing the appropriate construction method will improve the development and quality and reduce the hidden costs in the construction phase. Construction methods can be improved through construction technology innovation to control covert costs. Innovations in construction methods include innovations in construction processes, construction materials and equipment. Although the innovation of the construction method has cost input, it will greatly improve the construction process, so as to better ensure the quality and development of the construction.

\subsection{Information Communication Management}

Information communication problems can lead to hidden costs. Therefore, management information communication is a necessary measure to control the hidden costs in the construction phase of a construction project.

Information communication management should make a success of internal information control management and external communication information 
Table 3. Reliability statistics.

\begin{tabular}{ccc}
\hline Cronbach's Alpha & Cronbach's Alpha is based on standardized items & Number of items \\
\hline 0.856 & 0.886 & 31 \\
\hline
\end{tabular}

Table 4. Summary of the impact factors of the hidden costs of the construction project during the construction phase.

\begin{tabular}{|c|c|c|}
\hline Serial number & $\begin{array}{l}\text { Factors affecting hidden costs in the construction } \\
\text { phase of construction projects }\end{array}$ & Average score \\
\hline 1 & Initiative for staff work $\mathrm{C}_{1}$ & 3.25 \\
\hline 2 & Information flow control level $\mathrm{C}_{2}$ & 3.56 \\
\hline 3 & Professional competence and technical level $\mathrm{C}_{3}$ & 3.12 \\
\hline 4 & Information collection, organization and analysis capabilities $\mathrm{C}_{4}$ & 3.45 \\
\hline 5 & Subcontract management $\mathrm{C}_{5}$ & 3.88 \\
\hline 6 & Mechanical equipment repair and maintenance $\mathrm{C}_{6}$ & 2.96 \\
\hline 7 & Leadership decision level $\mathrm{C}_{7}$ & 3.02 \\
\hline 8 & The degree of perfection of the system and mechanism $\mathrm{C}_{8}$ & 3.03 \\
\hline 9 & Information transfer rate $\mathrm{C}_{9}$ & 3.21 \\
\hline 10 & Safety production management $\mathrm{C}_{10}$ & 2.86 \\
\hline 11 & Management organizational structure design $\mathrm{C}_{11}$ & 4.00 \\
\hline 12 & Quality assurance $\mathrm{C}_{12}$ & 3.88 \\
\hline 13 & Construction schedule $\mathrm{C}_{13}$ & 4.00 \\
\hline 14 & Duration guarantee $\mathrm{C}_{14}$ & 3.21 \\
\hline 15 & Determination of major construction steps and technical plans $C_{15}$ & 3.56 \\
\hline 16 & $\begin{array}{l}\text { Construction deployment and selection of construction methods } \\
\mathrm{C}_{16}\end{array}$ & 4.00 \\
\hline 17 & Construction site layout $\mathrm{C}_{17}$ & 3.89 \\
\hline 18 & Construction machinery and equipment selection $\mathrm{C}_{18}$ & 2.56 \\
\hline 19 & Progress payment amount $\mathrm{C}_{19}$ & 2.88 \\
\hline 20 & Project changes $\mathrm{C}_{20}$ & 3.68 \\
\hline 21 & Pad production $\mathrm{C}_{21}$ & 3.84 \\
\hline 22 & Timeliness of claim $\mathrm{C}_{22}$ & 3.02 \\
\hline 23 & Material equipment supply $\mathrm{C}_{23}$ & 4.00 \\
\hline 24 & Contract clause modification $\mathrm{C}_{24}$ & 2.88 \\
\hline 25 & Change in raw material prices $\mathrm{C}_{25}$ & 3.54 \\
\hline 26 & force majeure $\mathrm{C}_{26}$ & 2.55 \\
\hline 27 & Changes in laws and regulations $\mathrm{C}_{27}$ & 3.86 \\
\hline 28 & Industry policy adjustment $\mathrm{C}_{28}$ & 3.64 \\
\hline 29 & Engineering geological conditions $\mathrm{C}_{29}$ & 2.75 \\
\hline 30 & Inflation $\mathrm{C}_{30}$ & 2.54 \\
\hline 31 & Social security around the project $C_{31}$ & 2.65 \\
\hline
\end{tabular}


management. The information communication during the construction phase is not only the communication within the project organization but also the communication between the project organization structure and the owners, designers, supervisors, material suppliers and other parties.

\subsection{Reasonable Arrangements of Construction Progress}

Reasonable arrangement of construction progress is mainly to rationally divide the construction section, and to coordinate the development of each sub-project to achieve the greatest reduction in hidden costs.

It is important to strengthen overall control over the progress after a reasonable construction schedule has been developed. When managing the construction progress, it is necessary to comprehensively develop the schedule and carry out the dynamic control of the whole process to ensure the smooth implementation of the development target.

\subsection{Strengthening Subcontract Management}

Subcontracting occurs during the construction phase of most construction projects. Therefore, doing subcontract management is one of the important measures to control hidden costs.

1) The project department shall analyze the construction content of the construction project during the construction preparation stage. Develop a reasonable subcontracting plan and optimize subcontractors.

2) Establish a comprehensive subcontracting system and adopt a fine management and control model. The management of subcontracting is a comprehensive and comprehensive management of subcontractors. Strict subcontracting control measures are one of the effective ways to control the hidden costs in the construction phase. The progress of the subcontracting project directly affects the development of the project. Therefore, the progress of the subcontracted project should be refined, and the schedule and progress correction work should be strengthened.

\subsection{Strengthen Material Equipment Management}

Material equipment is an important aspect of the construction project. Management of material equipment mainly includes material equipment, supplier selection, material equipment arrival time control, and material equipment acceptance management.

At the same time as selecting the appropriate materials and equipment, it is necessary in order to strengthen the acceptance of materials and equipment. The construction phase of a construction project often only focuses on the selection and purchase of materials and equipment, while ignoring the inspection of materials. Therefore, for the inspection of materials and equipment, it is necessary to follow the applicable implementation standards and strict material entry inspection.

In addition to the above control measures, it is also necessary to strengthen 
the understanding of hidden costs for construction project participants to fundamentally control hidden costs.

\section{Conclusion}

In this paper, the related literature is studied. The factors affecting the hidden costs are analyzed from the four levels of technology, management, contract and society. 31 influencing factors are obtained. According to these indicators, index system of cost influencing factors in the construction stage is constructed, then, using expert scoring to determine the important influencing factors of hidden costs. At the management level, the main influencing factors are organizational structure design, subcontract management and information communication management; at the technical level, the main influencing factors are the choice of construction methods and the construction schedule; at the contract level, the main influencing factor is the supply of materials and facilities. Finally, in response to these main influencing factors, steps taken to control the hidden costs at this stage are proposed. As people slowly understand the hidden costs, their understanding will be still deepened, and their research will increase, and the research system will gradually improve.

\section{Conflicts of Interest}

The authors declare no conflicts of interest regarding the publication of this paper.

\section{References}

[1] Zheng, C.H. (2013) Implicit Cost: Funnel of Loss of Benefits. Management Manager, 2, 48-49.

[2] Robin, C.G. (2010) Implicit Cost Management. Management Accounting, 2, 132-152

[3] Robert, W. (2008) Construction Costs and Schedules. Energy Policy, 3, 317-333.

[4] Yang, W.S. (2014) Direct Cost Control of Engineering General Contracting Construction Phase Based on Target Cost Management. Journal of Shijiazhuang Railway University: Social Science Edition, 4, 60-63.

[5] Liu, C.Y. (2015) Causes and Control Strategies of Hidden Costs in Enterprises. Technology and Management, 4, 30-32.

[6] Ching, H. and Yu, C.H. (2011) A New Approach to Calculating Project Cost. International Journal of Project Management, 4, 131-138.

[7] Candy, B. (2013) Monitoring Systems and Their Effectiveness for Project Cost Construction. International Journal of Project Management, 2, 145-154.

[8] Wang, J.X. (2012) Discussion on Cost Management of Engineering Construction under Economic Environment. Journal of Shijiazhuang Railway University: Social Science Edition, 4, 35-38.

[9] Zhang, W.X. (2005) Uncertain Decision-Making Based on Rough Set. Tsinghua University Press, Beijing.

[10] Sun, Z. (2013) Construction Project Cost Control and Research. Xi'an University of Architecture and Technology, Xi'an. 